\title{
Correlation between Disability and Stigma on Leprosy Patient at General Public Hospital of Daha Husada Kediri
}

\author{
Srinalesti Mahanani ${ }^{1}$, Desi Natalia Trijayanti Idris ${ }^{1}$ \\ ${ }^{1}$ Lecturer at Kediri Baptist Hospital Health Science College, Indonesia
}

\begin{abstract}
Leprosy is a disease that has a high burden in the community or called triple burden disease. Support from the family increase the confidence of individual to interact with others and building positive relationships. The purpose of this study was to explain the correlation between family social support and the prevention of disability in patients with leprosy at General Public Hospital of Daha Husada Kediri. The research design was Cross Sectional. Respondents in the study of Leprosy Patients who met the inclusion criteria at outpatient as many as 50 respondents used purposive sampling data collection techniques. The variables were disability and stigma on leprosy patients. The research instrument used a questionnaire filled out by respondents and more than $50 \%$ have moderate stigma and degree of disability in leprosy at most respondents have grade 1. Spearman Rho Test results $\alpha<0.005, \rho=0.035$. The conclusion was that there is a relationship between disability and stigma on Leprosy Patient at General Public Hospital of Daha Husada Kediri.
\end{abstract}

Keywords: Leprosy Patients, Disability, Stigma.

\section{Introduction}

Leprosy is called triple bursden disease. Leprosy can be cured, but if not treated it can cause permanent disability ${ }^{1}$. Leprosy if not handled carefully can cause disabilities, and conditions become a barrier for leprosy patients in living a community life to meet their socioeconomic needs. It is hoped that a support system for people with leprosy will be able to provide full support in efforts to prevent disability with good family support for leprosy. Based on the pre-research at General Public Hospital of Daha Husada Kediri it was found that some respondents had level 1 and 2 disabilities.

According to Kunoli, leprosy is a chronic disease caused by bacteria that attack the skin and peripheral nerves. The cause of leprosy is the bacteria Mycobacterium Leprae. Leprosy can actually be prevented by early diagnosis and regular and accurate treatment with Multi-drug Therapy (MDT). ${ }^{2}$ The principle of preventing defects and their aggravation is basically checking the eyes, hands and feet regularly; protect the eyes, hands and feet from physical trauma and take care of themselves. ${ }^{3}$ Long leprosy sufferers will show leprosy reactions with nerve pain, weakness, some skin lesions, eye pain, or signs of systemic disease due to bacterial infiltration. attacking the respiratory mucosa, bones, and testes. If leprosy is left untreated, it can cause skin tissue damage (skin, upper respiratory mucosal, finger bones and face) and nerve damage (causing loss of sedation/muscle weakness that is supplied by the affected nerve).

The factor related to disability in leprosy sufferers is the role of the family. This role is related to efforts to prevent disability where the patient with the support of good family members takes preventive measures. The role of the family is very important for aspects of care for family members, especially in curative efforts (treatment). Every form of family social support has four characteristics, including informative, emotional attention, instrumental assistance and assessment assistance. ${ }^{4}$ The purpose of this study is to analyze the Relationship between Family Social Support and Disability Prevention for Leprosy Patients at General Public Hospital of Daha Husada Kediri.

\section{Method}

The design of this study used a cross sectional design, a study that emphasizes the time measurement/ observation of the independent and dependent variables only once at a time. The population of leprosy patients at General Public Hospital of Daha Husada Kediri is 
50 respondents. The sampling technique used in the study was purposive sampling. The dependent variable of this study is stigma, while the independent variable is disability. The research instrument used the ILEP stigma kueisoner and the WHO measure of disability. The analysis used in conducting hypothesis testing to determine the relationship between disability and stigma in leprosy is the Spearma rho test.

\section{Result}

Table 1: Stigma on Leprosy Patient at General Public Hospital of Daha Husada Kediri (May-June, 2020)

\begin{tabular}{|l|c|c|}
\hline Stigma Category & f & $\mathbf{\%}$ \\
\hline Mild & 0 & 0 \\
\hline Medium & 4 & 11,43 \\
\hline Moderate & 18 & 51,43 \\
\hline Heaviness & 13 & 37,14 \\
\hline Jumlah & 35 & 100 \\
\hline
\end{tabular}

Table 2: Degree of Disability on Leprosy Patient at General Public Hospital of Daha Husada Kediri (MayJune, 2020)

\begin{tabular}{|c|c|c|}
\hline Degree of Disability & f & \% \\
\hline 0 & 3 & 6,0 \\
\hline 1 & 35 & 70,0 \\
\hline 2 & 12 & 24,0 \\
\hline Jumlah & 50 & 100 \\
\hline
\end{tabular}

Table 3: Correlation between Disability and Stigma on Leprosy Patient At General Public Hospital of Daha Husada Kediri (May-June, 2020)

\begin{tabular}{|c|c|c|c|c|}
\hline & & & Degree of Disability & Stigma \\
\hline \multirow{2}{*}{ Spearman's rho } & Degree of Disability & $\begin{array}{l}\text { Correlation Coefficient } \\
\text { Sig. (2-tailed) } \\
\text { N }\end{array}$ & $\begin{array}{c}1.000 \\
50\end{array}$ & $\begin{array}{c}.299 * \\
.035 \\
50\end{array}$ \\
\hline & Stigma & $\begin{array}{l}\text { Correlation Coefficient } \\
\text { Sig. (2-tailed) } \\
\text { N }\end{array}$ & $\begin{array}{l}.299^{*} \\
.035 \\
50\end{array}$ & $\begin{array}{c}1.000 \\
50\end{array}$ \\
\hline
\end{tabular}

The results of the Spearman's Rho statistical test using computer software, based on the level of significance set at $\alpha<0.005$, the results obtained $\rho$ $=0.035$, it means that there is a relationship between disability and stigma in leprosy patients at General Public Hospital of Daha Husada Kediri.

\section{Discussion}

Prevention of Disabilities in Leprosy At General Public Hospital of Daha Husada Kediri.
Based on the results of a study of 50 respondents about the prevention of disability in leprosy at General Public Hospital of Daha Husada Kediri, the most respondents had sufficient disability prevention as many as $75 \%$ respondents

Disability is a term used to coverthree aspects, namely damage to structure and function (impairment), activity limitations and problems of participation (participation problems). These three aspects are very much influenced by individual factors and environmental factors. Efforts 
to prevent disability can be carried out at home, health centers or referral service units such as public hospitals or referral hospitals. Patients must understand that MDT treatment can kill leprosy germs. But defects in his eyes, hands or feet have already occurred and will remain throughout his life, so he must be able to carry out selfcare regularly so that the disabilities do not get worse. ${ }^{5}$

Behavior in an effort to prevent disability and increasing disability at home is sufficient. Many things affect the prevention of patient disability, namely the patient understands the condition of his body by carrying out the $3 \mathrm{M}$ principle, namely, checking the eyes, hands and feet regularly, protecting the eyes, hands and feet regularly, caring for the eye, hands and feet of physical trauma, caring for oneself. It can be proven that leprosy patients in examining their eyes, hands and feet have sufficient preventive behavior. It is supported by the results of the research that most of the knowledge about leprosy in general, however, knowledge in efforts to prevent disability through regular treatment is sufficient. In addition, the current level of disability also affects the prevention of disability, the disability experienced by lepers causes leprosy patients to be careful when doing a job, therefore people with leprosy must always protect, examine and care for their eyes, hands and feet so that disability does not increase to severe. ${ }^{6}$ This is evidenced by disability prevention obtained from 50 respondents, there are 5 respondents who have sufficient disability prevention behavior with a percentage $(75.4 \%)$ in statement number 12, namely so that I do not get hurt while working I do not do parts that are dangerous to my hands.

Based on the results of a study of 50 respondents regarding the prevention of leprosy disabilities at General Public Hospital of Daha Husada Kediri, Kediri, more than $50 \%$ of respondents examined their eyes, hands and feet, only $69.2 \%$ respondents.

Based on the theory, how to keep your eyes in good condition when your eyes feel dry is to close your eyes as often as possible. ${ }^{7}$ Often look in the mirror to see if there is a foreign object or redness in the eye. How to check the hands or feet when there are cuts or blisters can also affect the risk of deformity or increased defects. On the hands often stop and check the hands carefully for cuts or blisters, generally if the skin is Dry hands are accompanied by numbness causing muscle weakness or even paralysis. Therefore always check for possible dryness of the hands and fingers, check the hands regularly for injuries that may occur due to using the hands with bent fingers. On the feet, routinely check the feet for any parts of the feet that have cracks and injuries. Therefore, often stop and check the feet for even minor cuts or bruises or abrasions. ${ }^{3}$

Based on the results of behavioral leprosy patient research, it is sufficient to examine the eyes, hands and feet. This is because the patient understands enough about how to regularly check his eyes, hands and feet. This is evidenced by the prevention of disability obtained from 50 respondents, there are 9 respondents who have the behavior of examining their eyes, hands and feet both with a percentage $(84.1 \%)$ in statement number 8 , namely when walking I avoid friction from shoes/ sandals or sharp objects such as thorns, glass and wire to prevent injury to the leg. The age factor can also affect a person's health. The higher the age of a person, the bigger the person is also suffering from various diseases. The high age must be balanced with a healthy lifestyle such as routine checking of the eyes, hands and feet so that disabilities do not increase.

Based on the results of research from 50 respondents regarding the prevention of leprosy disabilities at General Public Hospital of Daha Husada Kediri, most of the respondents protect their eyes, hands and feet, only $78.8 \%$ respondents.

Protects the eyes, hands and feet from physical trauma. Provides protection to the eyes from dust and drying out the eyes. Protect your hands from objects or the environment that cause harm, for example: fire, knives, etc. Protects the skin of the hands from objects that are easy to cause injury such as: sharp objects, heat. Use tools for everyday activities that are modified for use by crooked fingers. To prevent the broken feet from getting more deformed, it is advisable to always wear shoes so that the fingers do not get tangled. Prevent dry skin by soaking feet for 20 minutes every day in plain water, rubbing the thickened area with direct rubbing stones, smearing (without drying) with coconut oil to moisture the skin. Protect your feet by wearing footwear, dividing household tasks so that other people do the dangerous parts if your feet are numb. ${ }^{8}$

Based on the results of research on leprosy patients in taking preventive measures by protecting body parts that can cause disability and increasing disability, this is because protecting the eyes and feet can reduce the risk of injury, so patients need to get education and attention 
every time they exercise control in health services. This is evidenced by the prevention of disability, obtained from 50 respondents, there are 4 respondents who have good behavior in examining their eyes, hands and feet with a percentage $(75.9 \%)$ in the statement about me not doing the part that is dangerous for numb feet. In addition, work also affects the prevention of protecting the eyes, hands and feet, the higher the workload, the higher the disability. This can be proven because most of the leprosy patients work as entrepreneurs, if the patient does not protect the eyes, hands and feet then the disability can occur and the disability will increase.

Based on the results of a study of 50 respondents regarding the prevention of leprosy disabilities at General Public Hospital of Daha Husada Kediri most of the respondents treated their eyes, hands and feet as many as $73.1 \%$ respondents.

Take care of the eyes, hands and feet. If they feel dry, give an eye patch at rest. If there is, no matter how small, take care and rest some of it until it heals. Soak for 20 minutes every day in water, clean thick skin (not drained) then smear with coconut oil or other oil to keep moisture. Caring often maybe every day using hands to straighten joints -Joint and prevent heavier stiffness. Take care of your semper legs so they don't get worse by sitting with your legs straight forward. Prevention of wounds if there are bruises or small abrasions, immediately treat and rest the feet until they heal, namely resting the feet. Give eye drops containing saline, if the eyes

Based on the results of the study of leprosy patients in the behavior of caring for the eyes and feet, it is sufficient to understand the things that cause disability. The consequences that occur are not done every day which can prevent disabilities and increasing disabilities in sufferers so it is very necessary to carry out preventive behavior, but patients tend not to pay attention in the act of caring for oneself. This is evidenced by the prevention of disability obtained from 50 respondents, there are 4 respondents who have good behavior in examining their eyes, hands and feet with a percentage (82.6\%) in statement number 18, namely I treat numb hands by avoiding hot objects and sharp. Therefore, the treatment that leprosy patients should do is soak for 20 minutes every day in water, clean the thick skin (not dried) then smear it with coconut oil or other oil to keep moisture, straighten joints and prevent heavier stiffness. ${ }^{9}$

Correlation between Disability and Stigma in Leprosy Patients at General Public Hospital of Daha Husada Kediri
The results of statistical tests using Spearman's Rho at the level of significance set at $\alpha \leq 0.05$ obtained results of $\rho=0.053$, where $\rho>\alpha$ which means there is a relationship between stigma and disability in leprosy patients at General Public Hospital of Daha Husada Kediri.

Based on the results of the data research, it was found that the majority of respondents experienced sufficient stigma, that is, most civil servants experienced severe stigma, namely 3 respondents or (75.0\%). The results of this study are inversely proportional to research (Soedarjatmi et al., 2009) Most of the patients do not work, apart from finding it difficult to find work for leprosy patients, they are afraid if their leaders and friends know that the respondent has leprosy and the respondent is very aware that fatigue will result in a recurrence of the disease. By not working, the respondent stated that they had no income.

Leprosy has a wide impact on the lives of sufferers, from marriage, work, personal relationships, business activities to their attendance at events in the community. Most of the respondents have suffered from leprosy between 1 year and 5 years, in this long period of time the respondent must always seek medication and take medication as regularly as possible, if it is late for treatment, the respondent states that the disease will reappear. Stigma causes discrimination so that it is difficult to find accommodation and work because of the clinical manifestations that arise and the complications that occur. People also feel reluctant to live side by side with leprosy patients. Most of the leprosy patients are civil servants because civil servants can elevate a person's social status to the highest level, giving more respect from society, so if leprosy patients get stigma then their social status will decrease. One of the impacts caused by stigma is the occurrence of physical disability. Based on the results of the study, it was found that the level of disability 2 was more than $50.0 \%$ namely $60.5 \%$ respondents. Stigmatization because physical disabilities are part of the group with physical deformities so that there are visible deformities in leprosy patients.

\section{Conclusion}

Leprosy patients at General Public Hospital of Daha Husada Kedirihave moderate stigma and disability degree is grade 1. However, there is a relationship between stigma and disability on leprosy patient at General Public Hospital of Daha Husada Kediri. 
For people with leprosy, they can take preventive measures for disability and increasing disability by implementing the $3 \mathrm{M}$ principle, checking, protecting and treating, so that disabilities do not increase and they can carry out activities so that they do not affect the fulfillment of daily needs. In addition, the need for health education to families and lepers about the importance of the role of the family in preventing disability to help the healing process for leprosy patients. ${ }^{10}$

Acknowledgement: We thank the Ministry of Science Research, Technology and Higher Education of Indonesia (RISTEKDIKTI RI) for Research Grants 2019 and providing 2020. We thank you to Director of Kediri Daha Husada General Public Hospital and all research respondents

Conflict of Interest: None to declare

Source of Funding: Ministry of Research and Technology/National Research and Innovation Agency Deputy for Research and Development Strengthening for Fiscal Year 2020.

Ethical Clearance: Ethical clearance from the Health Research Ethics Commission (KEPK) STIKES Kediri Baptis Hospital. This research has passed ethics with letter number 077/30/III/EC/KEPK-3/STIKES RSBK/2020.

\section{Reference}

1. Nsagha, D.S., Bissek, A. C. Z., Njuanda AL. Social Stigma as an Epidemological Determinant for Leprosy Elimination in Cameroon. J Public Health Africa. 2018;2.

2. Kunouli. Asuhan Keperawatan Penyakit Tropis. Jakarta: CV Trans Info Media; 2012.

3. Indonesia KR. Pedoman Nasional Progam Pengendalian Penyakit Kusta. Jakarta: Bakti Husada; 2012.

4. House. Buku Ajar Keperawatan Keluarga: Aplikasi Teori Pada Praktik Asuhan Keperawatan Keluarga. Jakarta: Trans Info Media; 2013.

5. Kesehatan K. Penanggulangan Kusta. Indonesia: Kementerian Kesehatan Republik Indonesia; 2019.

6. Wiwiek N. Gambaran Konsep Diri Klien Kusta. J Ilm Kesehat. 2013;5(2).

7. Susanto. Perawatan Klien Kusta Di Komunitas. Jakarta: Trans Info Media; 2013.

8. Dhelya W. Penyakit Kusta Sebuah Prespektif Klinis. Malang: UB Press; 2018.

9. Arianti PM. Psycoeducative Family Therapy Mempengaruhi Pengetahuan, Dukungan Keluarga dan Stigma Kusta. J Ners [Internet]. 2016;11(1). Available from: https://www.e-journal.unair.ac.id/ JNERS/article/view/1701

10. Rahman. Hubungan pengetahuan dan sikap masyarakat terkait kusta terhadap perlakuan diskriminasi pada pasien kusta. Med Respati. 2013; 11(3). 